\title{
Healthy Living: Are You at Risk for Dehydration? ${ }^{1}$
}

Jennifer Hillan ${ }^{2}$

Older adults often are at increased risk for dehydration.

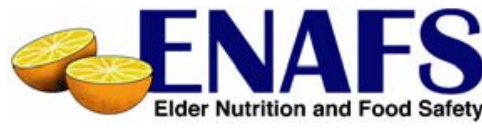

There are many reasons why you may be at risk. Some of these can be controlled, and some cannot. Find out if you are at risk for dehydration, and if so, how you can decrease your risk!

\begin{tabular}{|l|l|l|}
\hline & YES & NO \\
\hline I am older than 85 years. & & \\
\hline I am female. & & \\
\hline I have diabetes, urinary incontinence, or kidney disease. & & \\
\hline I have frequent fevers, vomiting, or diarrhea. & & \\
\hline I take laxatives, diuretics, or sedatives. & & \\
\hline I drink less than six cups of fluids each day. & & \\
\hline I often have dark yellow urine. & & \\
\hline I have problems swallowing. & & \\
\hline
\end{tabular}

If you answered "YES" to any of the statements above, you're likely at higher risk for becoming dehydrated. It's important to prevent dehydration, because it can lead to health problems. In severe cases, hospital treatment may be needed. Drink small amounts of fluids throughout the day, even if you aren't thirsty. Try plain or flavored water, fruit juices, low-sodium soups and vegetable juices, diluted sports drinks, and low-fat or fat free (skim) milk. Tea and coffee also can help you stay hydrated.

1. This document is FCS8847, one in a series of the Department of Family, Youth and Community Sciences, Florida Cooperative Extension Service, IFAS, University of Florida, Gainesville, FL 32611. First published: September 2007. Please visit the EDIS Web site at http://edis.ifas.ufl.edu

2. Jennifer Hillan, MSH, RD, LD/N, ENAFS nutrition educator, Department of Family, Youth and Community Sciences, Florida Cooperative Extension Service, Institute of Food and Agricultural Sciences, University of Florida, Gainesville, FL 32611.

The Institute of Food and Agricultural Sciences (IFAS) is an Equal Opportunity Institution authorized to provide research, educational information and other services only to individuals and institutions that function with non-discrimination with respect to race, creed, color, religion, age, disability, sex, sexual orientation, marital status, national origin, political opinions or affiliations. For more information on obtaining other extension publications, contact your county Cooperative Extension service. U.S. Department of Agriculture, Cooperative Extension Service, University of Florida, IFAS, Florida A. \& M. University Cooperative Extension Program, and Boards of County Commissioners Cooperating. Larry Arrington, Dean. 